\title{
A Blood Pact: the Significance and Implications of eIF4E on Lymphocytic Leukemia
}

\author{
V. VENTURI ${ }^{1,2}$, T. MASEK $^{1}$, M. POSPISEK ${ }^{1}$ \\ ${ }^{1}$ Laboratory of RNA Biochemistry, Department of Genetics and Microbiology, Charles University \\ in Prague, Czech Republic, ${ }^{2}$ Centre for Genomic Regulation, The Barcelona Institute for Science \\ and Technology, Barcelona, Spain
}

Received June 22, 2017

Accepted January 26, 2018

On-line March 12, 2018

\section{Summary}

Elevated levels of eukaryotic initiation factor 4E (eIF4E) are implicated in neoplasia, with cumulative evidence pointing to its role in the etiopathogenesis of hematological diseases. As a node of convergence for several oncogenic signaling pathways, eIF4E has attracted a great deal of interest from biologists and clinicians whose efforts have been targeting this translation factor and its biological circuits in the battle against leukemia. The role of eIF4E in myeloid leukemia has been ascertained and drugs targeting its functions have found their place in clinical trials. Little is known, however, about the pertinence of eIF4E to the biology of lymphocytic leukemia and a paucity of literature is available in this regard that prospectively evaluates the topic to guide practice in hematological cancer. A comprehensive analysis on the significance of eIF4E translation factor in the clinical picture of leukemia arises, therefore, as a compelling need. This review presents aspects of eIF4E involvement in the realm of the lymphoblastic leukemia status; translational control of immunological function via eIF4E and the state-of-the-art in drugs will also be outlined.

\section{Key words}

Eukaryotic initiation factor 4E • eIF4E • Lymphocytic leukemia • Translation initiation $\bullet$ Protein synthesis $\bullet$ Hematological diseases - Leukemia • ALL • CLL

\section{Corresponding author}

M. Pospišek, Department of Genetics and Microbiology, Faculty of Science, Charles University, Prague, Viničná 5, 12844 Prague 2, Czech Republic. Fax: +420221951 724. E-mail: martin@natur.cuni.cz

\section{Introduction}

Leukemic transformation is a convoluted biological process embracing changes in a gene cascade, which ultimately conduces to the clonal expansion of defective stem cells. Cellular growth and differentiation within the hematopoietic lineage are compromised by the build-up of genetic lesions, frequently resulting in altered tumor suppressive activities. These genetic events-along with epigenetic occurrences-induce leukemogenesis, the course of which has been correlated with deregulated levels of specific proteins. A convincing body of evidence points at aberrant control of protein synthesis as a condition favorable to malignant transformation, ultimately contributing to lymphoid neoplasmas (Ruggero et al. 2004). Emerging models reference the eukaryotic translation initiation factor 4E (eIF4E) as a key player in leukemic transformation: eIF4E mRNA and protein expression levels have been observed up-regulated in human malignancies as non-Hodgkin lymphoma (NHL) (Wang et al. 1999), acute (AML) and chronic myelogenous leukemia (CML) (Topisirovic et al. 2003), and acute lymphoblastic leukemia (ALL) (Zhu et al. 2013). Promises exist for novel drug design where the translational apparatus represents a primary therapeutic target. This review explores the significance of eIF4E in the context of lymphoblastic leukemias, delving into eIF4E factor regulation and clinical implications in the light of its long-established role in translation and a newly emerging one in leukemogenesis. Emphasis is on 
pathways that undergo dysregulation in the leukemic status while upholding a neoplastic phenotype through protein synthesis deregulation. The topic of myeloid leukemia has been dealt with by numerous authors; therefore, it will not be outlined hereinafter. Excellent reviews on the subject are available to interested readers with regard to the biology of myeloid leukemia (Shivarov and Bullinger 2014), its epigenetic landscape (Paluch et al. 2016), and current drug therapy (Jabbour 2016, Kadia et al. 2016).

\section{The lymphoblastic leukemic state}

Acute lymphoblastic leukemia (ALL) is a clonal malignancy that encompasses a group of precursor stage $\mathrm{B} / \mathrm{T}$ lymphoid cells during the earliest stages of their development, therefore impeding differentiation and maneuvering aberrant cell proliferation. The clinical heterogeneity of the disease progression and outcome, when comparing the pediatric population to adults, portrays quite distinctive biological subtypes. ALL is the most ordinary malignancy diagnosed in children (reviewed in Bhojwani 2015), accounting for over a quarter of all childhood cancers. Subtypes of ALL include both precursor $\mathrm{B}$ and $\mathrm{T}$ acute lymphoblastic leukemia, Burkitt's leukemia, and acute biphenotypic leukemia, yet this review will focus on B and $\mathrm{T}$ lymphoblastic leukemias exclusively. The preponderance of cases are of B-cell origin; however, ALL can besides arise from lymphoblasts committed to the T-cell lineage, a form of leukemia in which the malignant cells express immature T-cell immunophenotypes. Typified by small to medium-sized blast cells with inadequate cytoplasm, T-ALL portends an unfavorable prognostic outlook than B-precursor ALL in that it is characterized by chemotherapy resistance and frequent relapse (Tariq $e t$ al. 2009). Current treatment regimens encompass risk-adapted chemotherapy, hematopoietic stem-cell transplantation, and comfort care; improved therapy strategies for T-ALL with reduced long-term toxicities remain nevertheless a compelling need.

Chronic lymphocytic leukemia (CLL) is a condition characterized by a progressive accumulation of monoclonal B lymphocytes that preferentially affects adults over the age of 55, a disproportionate number of whom are males; while it occasionally occurs in younger adults, it appears to leave children mostly unaffected. As a low-grade lymphoproliferative disorder, CLL follows an indolent clinical course and, owing to its relatively longer survival rate, is the most common leukemia within the Western world's adult population (Redaelli et al. 2004). B-cell chronic lymphocytic leukemia (B-CLL) has the highest diagnostic recurrence among clinical entities of leukemic nature and is characterized by the progressive accumulation of immunologically competent, phenotypically mature B lymphocytes. T- and B-cells are usually associated with specific CD markers (Montillo et al. 2005, Niu et al. 2013) that discriminate on cell type (T- from B-) and diverse maturation stages; however, reports exist for cases of B-CLL that aberrantly co-express two T-cell-associated antigens (Espinosa et al. 2003, Jani et al. 2007). One of the most aggressive CLL subtypes is B-cell prolymphocytic leukemia (PLL), an extremely rare disease comprising less than $1 \%$ of $\mathrm{B}$ cell leukemias. This kind of leukemia may occur by itself, concurrently with CLL or, in due course, CLL may turn into PLL, which progressively tends to worsen more quickly (Yamamoto and Goodman 2008). CLL differs from other leukemic diseases staging since most patients are asymptomatic or only mildly symptomatic at the time of diagnosis and do not require immediate treatment. Once a so-called "incurable" disease in the elderly, CLL can nowadays be fairly effectively alleviated with current standard treatments. Protracted remissions and enhancements in survival rates are improving, albeit a complete remission stage is unlikely to be attained with the current state of medical intervention and novel therapeutic strategies and drug candidates are utterly awaited.

\section{The eukaryotic initiation factor $4 \mathrm{E}$}

In eukaryotes, a majority of cellular mRNAs is translated via cap-dependent translation (reviewed in Merrick et al. 2004, Sonenberg and Hinnebusch 2009). The $\mathrm{m}^{7} \mathrm{GpppN}$ cap structure present at the $5^{\prime}$-end of messenger ribonucleic acids is bound by eIF4E as a part of the eIF4F complex (Grifo et al. 1983, Sonenberg et al. 1978). A multisubunit structural entity, eIF4F consists of the rate limiting factor eIF4E and its interaction partners, the scaffolding protein eIF4G and the DEAD-box helicase eIF4A. eIF4E role is, however, not constrained to the pre-initiation complex: this key translation factor functions also in mRNA-related events as nucleocytoplasmic transport of mRNA and its sequestration and protection against exonuclease decay. Critical to gene expression, the step of translation initiation presides over the making of individual protein components by 
restraining the levels of cap-binding complex elements and mRNAs. Perturbations over translation control have dramatic biological effects and are a primary occurrence in malignancies (Ruggero et al. 2004). The least abundant of the initiation factors, eIF4E is overexpressed in many cancers and plays pivot roles in the development and progression of hematological malignancies in animal models and humans (Wang et al. 1999), rendering it an alluring target for the treatment of leukemias. The transformation activity of eIF4E is, however, not limited to its role in translation: close ties exist between eIF4E-dependent mRNA export and oncogenic transformation (Culjkovic-Kraljacic et al. 2012). The stability of eIF4E mRNA (Topisirovic et al. 2009) and dysregulation of related cellular processes as P-bodies and stress granules formation (Andrei et al. 2005, Kedersha et al. 2005, Frydryskova et al. 2016) could also contribute to eIF4E transformative capacity and deserve further investigation. Translational control of eIF4E activity is multi-level regulated by diverse cellular processes (Fig. 1). Among the better understood are the phosphorylation event which allows eIF4E to bind the 5' cap structure, the regulation of eIF4E expression level, and its interaction with translational repressor 4E-BPs. Translational control of eIF4E expression is implicated in many cancers; concordantly, eIF4E transforming properties have been linked to its ability to promote translation of genes involved in proliferation and survival. Based upon this evidence eIF4E has been acknowledged as an oncoprotein (Mamane et al. 2007). eIF4E overexpression leads to increased expression of a subset of mRNAs, many of which encoding mediators of the mitogenic response. Among them are the protooncogene c-Myc, the core component of the cell cycle machinery cyclin D1, B-cell lymphoma 2 (Bcl-2) protein, cyclin-dependent kinase 2 (CDK-2), the apoptosis inhibitor survivin, and the ornithine decarboxylase enzyme (Culjkovic et al. 2005, Culjkovic et al. 2013, De Benedetti et al. 1994, Rosenwald et al. 1995). At the nuclear level, eIF4E regulates the export-and subsequent expression-of many messenger RNAs implicated in cell cycle progression via the existence of a nucleotide structural element in the 3 ' UTR of the given transcripts (Culjkovic et al. 2005). Deregulation of eIF4E-mediated mRNA export has been shown to play a significant role in lymphomagenesis (CuljkovicKraljacic et al. 2016). In AML cells, most of the eIF4E is found in the nucleus, highlighting the importance to target nuclear mRNA export in addition to effects on translation. Importantly, the movement of eIF4E to the cytoplasmic compartment correlates with remissions (Assouline et al. 2015). Although prominently relevant, not all dysregulated translation in cancer is driven by eIF4E. Other translation factors play a role in neoplastic transformation via a cap-dependent mechanism: for instance, overexpression of a number of eIF3 subunit proteins has been proposed to contribute to malignant phenotypes (Zhang et al. 2007).

\section{Translational control of immunological function via eIF4E}

As a site of control over the immune system's activity, eIF4E has attracted the attention of cancer immunologists. Translational control of immunological function via the eIF4E node endures modulation by mammalian target of rapamycin complex 1 (mTORC1)-dependent inactivation of 4E-BPs and direct phosphorylation by the Mnk1/2 kinases (Beretta et al. 1996, Ueda et al. 2004). Besides, increases in eIF4E activity can be achieved by affecting its mRNA stability (Topisirovic et al. 2009) and/or stimulating its expression at the transcriptional level (e.g. via the transcription factor c-Myc). Given that the majority of eIF4E-sensitive 5' capped transcripts encode proliferation and antiapoptotic polypeptides, it is not surprising that leukemia research efforts have been directed towards modulating eIF4E expression, functions, and inter-related routes. So far, the most satisfactory results have been achieved in the treatment of AML, however, a number of exciting research efforts are raising the prospect of significant headways in the cure of lymphocytic leukemias.

Among its reported activities, eIF4E acts as a downstream effector of the serine/threonine kinase mTOR complex 1 (mTORC1) the elevated activity of which is a prominent feature of cancer cells, including hematological malignancies (Vu and Fruman 2010). As anticipated in the text, eIF4E binds the $5^{\prime}$ cap structure present on cellular mRNAs and initiates protein synthesis by virtue of its ability to associate with eukaryotic initiation factor $4 \mathrm{G}$ (eIF4G) and helicase eIF4A. Binding of eIF4E to scaffold protein eIF4G is restrained in a competitive manner by translational inhibitors, 4E-binding proteins (4E-BPs); upon mTOR-mediated phosphorylation, 4E-BP1 decreases its affinity for eIF4E and, by freeing the binding site, facilitates the joining of eIF4G thereby enhancing cap-dependent translation. 
Conversely, induction or activation of the tumor suppressor protein p53 rapidly leads to 4E-BP1 dephosphorylation (Constantinou et al. 2008), resulting in sequestration of eIF4E, decreased formation of the eIF4F complex and consequent inhibition of protein synthesis. The mTORC1-4E-BP-eIF4E pathway is regarded as an important axis that affects the translation of several proteins with central roles in immunology, e.g. the interferon regulatory factor IRF7, trans-acting T-cell-specific transcription factor GATA-3, and the cytokine interleukin 4 (IL-4) (Colina et al. 2008, Cook and Miller 2010, Gigoux et al. 2014).

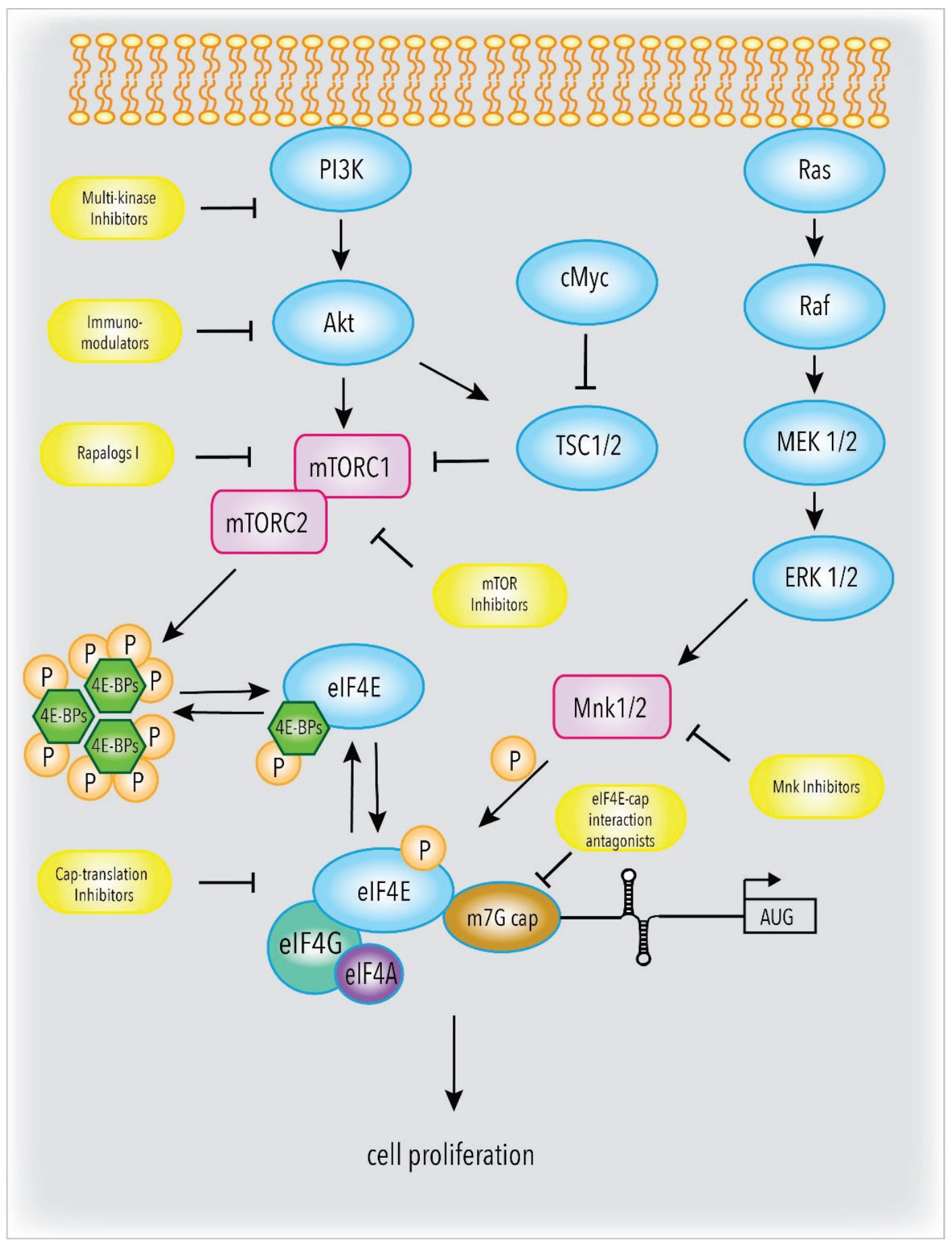

Fig 1. Mechanisms of translation initiation control via the eIF4E hub are pertinent to deregulated lymphoblastic activity. In the realm of lymphoblastic leukemia therapeutical interventions, targeting eIF4E have been attempted by mimicking of the $5^{\prime}$ cap structure (Ribavirin, 4Ei-1), inhibition of eIF4E specific MNK1/2 kinases, cap-translation inhibitors disrupting eIF4E-eIF4G factors binding (4EGI-1), immunomodulators (Lenalidomide and Ofatumumab) and inhibition of the PI3K-Akt-eIF4E axis (Sorafenib) and either one (first generation rapalogs) or both (PP242) mTOR complexes. eIF4E hub inhibitors are discussed in detail in the text. 


\section{eIF4E levels and T cells activation}

Signals generated from the T-cell receptor (TCR) can trigger the activation of $\mathrm{T}$ cells from their naïve or quiescent state with a subsequent increase in processes as transcription, synthesis of DNA, and protein synthesis (Cooper 1969, Crabtree and Clipstone 1994). Polysome profiling analysis shows that activated $\mathrm{T}$ cells undergo a rapid increase of their protein synthesis levels, along with an augmented ratio of translation/ribosome (Cooper and Braverman 1977). An investigation over translation rates looking at eIF4E phosphorylation and effects of TCR stimulation conducted on thymocytes demonstrated a severe change in eIF4E activity following activation of these hematopoietic progenitor cells (Beretta et al. 1998). Furthermore, activation of human peripheral blood T cells by cross-linking of TCR-CD3 results in a strong increase in translation rates and expression of initiation factors (Mao et al. 1992). T cell development and activation are usually accompanied by assembly of proteins that require active translation, an early happening in activated T cells; eIF4E protein level increases during the first $24 \mathrm{~h}$ (Boal et al. 1993) and later even double in $\mathrm{T}$ cell activation (Nikolcheva et al. 2002). This event occurs before or concurrently with the cellular appearance of RFLAT-1, a transcription factor of lateactivated T lymphocytes-1, and hints at a role for eIF4E in the induction of RFLAT-1 protein expression. Overexpression of eIF4E increases RFLAT-1 protein level, whereas inhibition of Mnk1-a kinase which phosphorylates eIF4E that increases its affinity for the mRNA cap-diminishes RFLAT-1 production rate (Nikolcheva et al. 2002). Echoing the notion that RFLAT-1 expression endures a cap-dependent regulation mechanism, involving eIF4E and Mnk1, are data evidencing that Mnk1 and Mnk2 kinases are required for $\mathrm{T}$ cell development and activation (Gorentla et al. 2013). In consideration of these findings, the prospect that eIF4E and its physiological Mnk1/2 kinases might be selectively required for efficient translation of specific protein subsets affecting $\mathrm{T}$ cell responses cannot be dismissed.

\section{eIF4E and memory T lymphocytes generation}

The vast majority of lymphocytes is represented by $\mathrm{CD} 4+\mathrm{T}$ and $\mathrm{CD} 8+\mathrm{T}$ cells, the immunological memory of which is an essential component of protective immunity. In CLL patients, these cells are functionally impaired and exhibit features of $\mathrm{T}$ cells exhaustion (Riches et al. 2013). Therefore, developing strategies to induce an effective response in memory $\mathrm{CD} 4+\mathrm{T}$ and
CD8+ $\mathrm{T}$ cells represents a major ambition in cancer immunology. CD4+ T helper cell lineage differentiation is defined by expression of specific transcription factors required for cell subset identity (Wong et al. 2011). Among them Foxp3, a member of the forkhead box family, acts a key regulator by effecting lineage commitment and impacting $\mathrm{T}$ regulatory cell (Treg) development and function.

Bjur et al. (2013) reported the first genome-wide investigation on translational control in primary $\mathrm{CD} 4+$ cell subsets, unveiling mRNA specific quanti- and qualitative differences in the translatome profiles of these cellular subgroups. eIF4E mRNA was favorably translated in activated effector $\mathrm{T}$ (Teff) cells compared to activated regulatory $\mathrm{T}$ (Treg) cells; in agreement with the mRNA level, eIF4E protein level was also greater in activated Teff cells. Importantly, polypeptides translated from eIF4E-sensitive, cell cycle-related mRNAs showed higher level of expression in activated $\mathrm{T}_{\mathrm{Foxp} 3-}$ cells versus activated $\mathrm{T}_{\mathrm{Foxp} 3+}$ cells. Thus, to an extent, the diverse translatomic landscapes of activated $\mathrm{T}$ cell subsets can be rationalized as a consequence of different eIF4E levels. In parallel to a greater eIF4E expression, translation of mRNAs comprising cyclins was augmented in activated Teff cells, echoing to the rationale that mRNAs engaging in cell cycle progression are more susceptible to eIF4E regulation. Along with cell cycle, other biological functions (i.e. ubiquitination and chromatin modification) were found to be co-regulated by eIF4E, strongly suggesting that a module of gene expression exists at eIF4E-dependent translational level in CD4 $+\mathrm{T}$ cell subsets. Making use of an eIF4E cap binding inhibitor, the pro-drug 4Ei-1, Foxp3 expression could be induced in activated Teff cells upon inhibition of eIF4E activity under undifferentiating conditions, a finding that mirrors the lower eIF4E level observed in activated Treg cells. Differential thresholds of eIF4E levels between Teff and Treg cells seem to dictate translational pattern of eIF4E-sensitive, cell cycle-related mRNAs that, in turn, direct proliferation and ultimately define $\mathrm{CD} 4+\mathrm{T}$ cells lineage commitment. Translational control permits to promptly induce or terminate protein synthesis of specific polypeptides required during the inflammatory process. Activation of mTOR signaling by diverse environmental triggers might modulate eIF4E activity, regulate its translational activity on eIF4E-sensitive mRNA, and ultimately orchestrate $\mathrm{T}$ cell subset-specific responses. Bjur and colleagues' insightful investigation attests to the significance of translational control in the regulation of 
proliferation of $\mathrm{T}$ cell subgroups; it remains yet to be defined whether eIF4E activity modulates $\mathrm{T}$ cell lineage identity via a direct or an indirect fashion.

Lindquist et al. (2011) evaluated the presence of cytotoxic $\mathrm{CD} 4+\mathrm{T}$ cells-including Tregs-in the peripheral blood of patients affected by B-CLL, pre-B ALL, and B-cell lymphoma. Although these hematological cancers share the same B-cell origin, they differ with respect to the $\mathrm{B}$ cell maturation stage and the anatomical location of the leukemic cells. Elevated levels of Tregs and $\mathrm{CD} 127^{\text {high }} \mathrm{FoxP}^{+}$cells were determined in patients affected by CLL and both CD4+ FoxP3+ and CD4+ FoxP3- $\mathrm{T}$ cells from patients with B-cell malignancy express cytolytic markers. Overall, cytotoxic populations of $\mathrm{CD}^{+} \mathrm{T}$ cells, including Tregs, are present in patients with B-cell malignancies and may be an important factor in immune-related disease control. A scenario is conceivable in which hematopoietic cancer cells are regarded as immune cells by the immune system. Under this assumption, the malignant $\mathrm{B}$ cells would be susceptible to regulation by $\mathrm{CD} 4+\mathrm{T}$ cells as well as Tregs. Echoing this hypothesis is a report on more favorable survival outcomes for patients with B-cell lymphoma who have a greater number of $\mathrm{FoxP}^{+}$cells within the tumor (Tzankov et al. 2008). It seems plausible to postulate that eIF4E levels could be regulated in response to changes in the local inflammatory environment and, by this means, spanning the extracellular microenvironment, genetic programming, and consequential biological responses. Giving the significance of $\mathrm{CD} 4+\mathrm{T}$ cell subsets and their roles in immunity mechanisms, exposing regulatory processes that lie beneath gene expression affecting $\mathrm{T}$ cell function is of paramount relevance for therapeutic discovery.

mTOR, regulates memory CD8 T cell differentiation and, counterintuitively to its immunosuppressive nature, the mTOR specific inhibitor rapamycin shows unexpected immunostimulatory effects on the generation of memory CD8 T cells (Araki et al. 2009). Taking advantage of a retrovirus-based RNAi system, Araki et al. (2009) investigated the consequences of distinctively knock-down various genes within the mTOR pathway (i.e. $\mathrm{mTOR}$, its regulatory-associated protein raptor, ribosomal protein S6 kinase 1 (S6K1), eIF4E, and the immunophilin FKBP12) in antigen specific CD8 $\mathrm{T}$ lymphocyte cells. Retroviruses marked by GFP and expressing RNAi for a given gene or a control retrovirus were used to infect lymphocytic choriomeningitis virus (LCMV) specific transgenic CD8 T cells and these transduced cells were then transferred into naïve mice, followed by LCMV infection. Pursing more insight into mTOR-regulated cell memory formation, the authors examined the role of S6K1 and eIF4E: knockdown of such mTORC1 downstream effectors significantly enhanced memory CD8 T cell differentiation, thereby suggesting that mTOR exerts its effect through these downstream proteins (Araki et al. 2009).

The mTORC1-4E-BP-eIF4E signaling pathway and cell cycle in lymphocytes

Cellular protein synthesis plays an explicit role in cell cycle progression. Appropriate cell size and geometry are prerequisites to enter and successfully complete the cell division process. Altogether, a growing body of literature indicates eIF4E as a mediator of mTOR-dependent cell cycle control.

Fingar and colleagues (2004) identified the 4E-BP-eIF4E pathway as one of the major mTORdependent downstream signaling routes in mediating G1 phase progression. The expression level of eIF4E is the determining factor in whether eIF4E triggers a negative feedback loop to constrain deviant cell cycle progression and proliferation. Interestingly, cells overexpressing eIF4E displayed: a) a minor, however significant, acceleration of $\mathrm{S}$ phase entry when rapamycin-treated; b) an increase rate of G1 phase progression from quiescence to $\mathrm{S}$ phase in a rapamycinfree environment. Simultaneous downregulation of both S6K1 and 4E-BP-eIF4E pathways impedes G1 phase progression to a degree comparable to that elicited by mTOR inhibitor rapamycin (Fingar et al. 2004).

The transitional repressors 4E-BPs are key mTOR effectors controlling growth and proliferation in activated $\mathrm{B}$ and $\mathrm{T}$ cells. Making use of an inducible in vivo system So et al. (2016) showed that inhibition of eIF4E was sufficient to impede lymphocytes growth and proliferation. Accordingly, deletion of 4E-BPs partially rescued $B$ cells from the effects of mTOR inhibition. In lymphocytes, rapamycin disrupted eIF4E function due to an abundance of 4E-BP2 over 4E-BP1 in these specific cells and their greater sensitivity to this drug. It was concluded that $4 \mathrm{E}-\mathrm{BP} 1 / \mathrm{eIF} 4 \mathrm{E}$ route is rapamycin sensitive in lymphocytic cells only where it affects clonal expansion by coordinating both growth and proliferation (So et al. 2016).

eIF4E and Mnk1/2-direct phosphorylation events

Besides the modulation exerted by the 
mTORC1-4E-BP pathway, studies have also linked the Mnk1/Mnk2-eIF4E route to mechanisms controlling immunological functions. Indispensable for eIF4E phosphorylation but not for cell growth, Mnk1 and Mnk2 are eIF4E kinases (Ueda et al. 2004) that control protein synthesis via regulating its activity. In genetically engineered mouse lymphoma models, eIF4E-mediated transformation is dependent of its ability to start translation via phosphorylation on serine 209 (Ser209). While the precise mechanism through which eIF4E phosphorylation mediates malignant transformation in these models is yet elusive, no uncertainty surrounds the absolute requirement for Mnk1/2-mediated Ser209 phosphorylation for eIF4E oncogenic activity (Wendel et al. 2007). Non-phosphorylable forms of eIF4E are less efficient in causing in vivo transformation, highlighting the therapeutic potential for targeting the Mnk1/2 kinases to impede eIF4E-mediated transformation (Konicek et al. 2011, Ueda et al. 2010). Notably, targeting mTOR and Mnk1/2-eIF4E routes concurrently conducts to a more potent antileukemic response than the solo targeting of each pathway (Altman et al. 2010). A recent investigation from Lim et al. reports the Mnk1/2-eIF4E axis as a significant controller of blast crisis (BC) self-renewal (Lim et al. 2013), endorsing therapeutic exploration into Mnk1/2 kinase pharmacologic inhibition. To date, however, promising results seem to be confined to $\mathrm{BC}$ chronic myeloid leukemia. The effect of Mnk1/2 on tumorigenesis occurs probably through eIF4E phosphorylation (Furic et al. 2010); however, Mnk1/2 affects the malignant process also via other targets e.g. hnRNPA1, a nuclear ribonucleoprotein which is phosphorylated in response to T cell activation (Buxadé et al. 2005), Sprouty2 (DaSilva et al. 2006) and cPLA2 (Hefner et al. 2000).

eIF4E and proto-oncogene c-Myc-induced protein synthesis

Neoplastic conditions are commonly associated with elevated levels of eIF4E (Zhu et al. 2013); a remarkable increase in its activity is achieved by enhancing its expression via activation of given transcription factors (Jones et al. 1996). Elements of the protein synthesis machinery are established targets of c-Myc whose ability to regulate the transcription of such components has been validated in several cell types. eIF4E itself is a long-known c-Myc target (Rosenwald et al. 1993) and more recent work from Lin et al. (2008) establishes the remaining two components of the eIF4F complex, eIF4A and eIF4G, as bona fide c-Myc targets. The same authors suggested a positive cascade loop between c-Myc and the eIF4F complex as a contributing factor to lymphoma development (Lin et al. 2008). Nevertheless, the cellular consequences, the specifically involved messenger RNAs, and the stages guiding neoplastic transformation triggered by c-Myc-dependent augmented protein synthesis remain ill-defined. Transcription factor c-Myc has been found implicated in B-cell lymphomagenesis (Ruggero et al. 2004) and is frequently overexpressed in T-ALL (Palomero and Ferrando 2008) where it acts in cooperation with eIF4E in the development of such malignancy. c-Myc mRNA is itself a translational target of eIF4E exerting a feedback mechanism on the so-called RNA regulon (reviewed in Culjkovic et al. 2007): c-Myc promotes the transcription of eIF4E (Schmidt 2004), which, in turn, translationally stimulates c-Myc mRNA expression (Lin et al. 2008). Furthermore, eIF4E activity is regulated by c-Myc via stimulation of mTOR-mediated 4E-BPs phosphorylation (Pourdehnad et al. 2013). The reciprocal dependency of eIF4E and c-Myc has the potential to be exploited therapeutically to take action against c-Myc driven malignancies, expressly c-Myc driven lymphomas which are highly dependent on 4E-BP1.

An investigation carried out on transgenic mice in which eIF4E expression is driven by the $\beta$-actin promoter ( $\beta$ T-eIF4E) found B-cell lymphoma among the most represented cancer types (Ruggero et al. 2004). Tumor initiation occurs relatively late during the life time of these animals, a latency suggesting that eIF4E may cooperate with additional oncogenic events in tumor development. One contribution towards leukemogenesis comes from the circuital activity of eIF4E and the critical gene regulator c-Myc. An effective, genetic cooperation lies behind: eIF4E suppresses c-Myc proapoptotic function, therefore resulting in a marked acceleration of B-cell lymphomagenesis; on the other hand, c-Myc antagonizes the proliferative disadvantage resulting from eIF4E-dependent senescence (Ruggero et al. 2004).

Mechanisms of protein translation control through IncRNAs have been recently described (Gumireddy et al. 2013, Yoon et al. 2012) and some clarification on the regulation of c-Myc translation was presented: growth arrest-specific 5 (GAS5), a lncRNA linked to normal growth arrest in both leukemic and untransformed human lymphocytes, interacts and cooperates with eIF4E to regulate c-Myc translation through IncRNA-mRNA interaction. The same 
publication informs on how, under mTOR regulation, GAS5 lncRNA is recruited to the translation initiation complex eIF4F via direct binding with eIF4E (Hu et al. 2014).

\section{p53 regulation of eIF4E}

Activation of mTOR1 can reduce the levels of cellular tumor antigen p53 via eIF4E (Mungamuri et al. 2006); in turn, p53 is involved in the regulation of eIF4E expression through its interaction with the protooncogene c-Myc, thereby preventing c-Myc binding to eIF4E promoter (Zhu et al. 2005). Inactivation of the p53 pathway is a universal event in human cancers and promotes tumorigenesis and resistance to chemotherapy. Mutations in p53 have been linked to hematological malignant diseases, although with a minor incidence than in solid tumors (Krug et al. 2002). Direct inactivating p53 mutations are infrequent in non-complex karyotype leukemias, suggesting that the p53 pathway must endure inactivation via alternative mechanisms (Schittenhelm et al. 2013). Following finding of induction of wt-p53 repressed eIF4E expression in acute lymphoblastic EU-3 cells, Zhu and colleagues (2005) deduce an association between elevated eIF4E expression levels, its tumorigenicity, and defects in p53. The same authors suggest eIF4E expression as being under the mutual regulation of $\mathrm{p} 53$ and c-Myc; hence, loss of p53-mediated control over c-Myc-dependent transactivation of eIF4E might promote neoplastic transformation in an eIF4E-dependent fashion (Zhu et al. 2005). eIF4E promoter activity is constrained by p53 gene transfection, whereas inactivation of p53 following overexpression of the murine doubleminute 2 onco-protein (MDM2) human homolog results in stimulation of eIF4E promoter activity (Zhu et al. 2005). A tumor-associated antigen (TAA), MDM2 is overexpressed in hematological malignancies (Jones et al. 1988) where it prompts an immune response and is presented as TAA in CLL human cells aiding tumorspecific T cells proliferation (Mayr et al. 2006). Hsu et al. (2011) described a strong association between elevated eIF4E levels and increased expression of MDM2 in esophageal cancer, providing further evidence of the balanced regulatory loop between p53 and eIF4E activities.

eIF4E-Notch regulation in T/B cell lymphocytic leukemia

The family of transmembrane Notch receptors plays a pivotal role in cellular fate along with a recognized importance in ordinary lymphocyte function (Radtke et al. 1999, Wolfer et al. 2002). Abnormal regulation of Notch is held as responsible in the development and progression of human malignancies including leukemia, where Notch aberrant signaling exhibits either an oncogenic or tumor suppressive nature with conceivable context-dependent features (Gothert et al. 2007). Notch 1 mutations triggering its continuous signaling were uncovered in nearly $60 \%$ of T-ALL patients, making Notch 1 the most prominent oncogene involved in the pathogenesis of T-ALL (Weng et al. 2004). Studies from Zou et al. (2013) have unveiled that Notch1 signaling is required for multiple pathogenic processes in T-ALL (Zou et al. 2013), suggesting that pharmacological inhibitors of Notch1 signaling may be attractive interventions for T-ALL treatment. The exact mechanism through which Notch1 induces leukemogenesis remains to be fully characterized since it has become apparent that the NOTCH1 mutations uncovered in human T-ALL display only a feeble oncogenic activity (Ntziachristos et al. 2012). Thus, within the Notch pathway, additional initiating and collaborating genetic events may be involved in the initiation and progression of T-ALL.

The Notch pathway exerts control over eIF4E directly via c-Myc and indirectly via the c-Myc-tuberous sclerosis complex-mTOR-4E-BP1 axis (Schmidt 1999). Notch further regulates post-transcriptional events by promoting the expression of $\mathrm{HuD}$ (Bellavia et al. 2007), an RNA-binding protein expressed in human T-ALL which co-localizes with both eIF4E and the translation initiation complex component poly(A)binding protein (PABP) (Bolognani et al. 2010). Notch signaling contributes to apoptosis resistance in CLL in part by sustaining antiapoptotic protein Mcl-1 expression. Mcl-1 downregulation by Notch targeting is accompanied by reduced phosphorylation of eIF4E, indicating this key translation initiation factor as an additional target of the Notch pathway in CLL cells (De Falco et al. 2015).

\section{Leading the path towards cure}

Significant progress has been attained in understanding the biological core behind leukemia occurrence. Within clinical research, efforts are spent on elucidating the mechanisms of resistance to current available medications, while advancements in medical therapies stemming from molecular biology lead the quest for better drugs. In the context of clinical stage, 
outcomes are still substantially inconsistent, demanding for additional markers to predict survival and direct management in early staged leukemic patients. CLL is considered incurable, except possibly in a minority of patients whose physical conditions make a stem cell transplant bearable. New treatments, or better combinations of the existing ones, are demanded to overcome the deadlock we appear to have come in the treatment of leukemia at its acute stage of development. The prospect of effectively targeting eIF4E and its interrelated signaling routes in leukemia therapy is alluring, given that eIF4E is a downstream node on which multiple oncogenic signaling pathways converge. To date, however, efforts in this direction have yielded limited clinical success.

\section{mTOR Kinase Inhibitors}

A variety of rapamycin analogue agents (rapalogs) have been employed with success to target mTOR signaling pathway in a number of malignant hematological occurrences and demonstrated significant preclinical activity against ALL, thereby prompting a considerable number of clinical trials. Owing to the synergistic effects shown with conventional cytotoxic agents (e.g. methotrexate and corticosteroids), mTOR inhibitors are able to overcome pathways of chemotherapeutic resistance affecting conventional ALL treatment. Whereas first generation rapalogs only achieve an incomplete block of mTOR downstream signaling by targeting one element of the pathway (i.e. mTORC1), newer molecules are designed to target different kinases within the PI3K/AKT/mTOR route (e.g. PI3K, mTORC1 or mTORC2). A number of pharmaceutical agents under development have their target(s) extended to other path components, comprising eIF4E and the phosphoinositidedependent protein kinase 1 (PDPK1). Recent studies on T-ALL cells reveal that, although mTORC1 or mTORC2 knock-down diminishes proliferation of blasts, only the severe constraint of both mTOR complexes via eIF4E knockdown or inhibitor compounds instigate their death (Schwarzer et al. 2014), corroborating the notion that mTOR-driven leukemogenesis crucially hinges upon augmented cap-depend translation.

A novel dual mTOR ATP active site inhibitor, PP242, targets mTOR kinase functions in both complexes (TORC1 and TORC2) and modulates the activity of key components of the translational apparatus. This compound encouragingly exhibits elevated selectivity towards leukemic cells versus normal bone marrow and peripheral blood lymphocytes (Janes et al. 2010). Notably, PP242 attains inhibition of cap-dependent translation under conditions in which rapamycin is ineffective (Feldman et al. 2009) and its antileukemic activity is reported to be influenced by eIF4E phosphorylation levels at its major phosphorylation Ser209 site (Shi et al. 2015). A study on human leukemic cells revealed PP242 prominent cytotoxic effect on the Philadelphia-positive $(\mathrm{Ph}+)$ ALL SUP-B15 cell line, expressly in combination with the anthracycline daunorubicin (DNR). DNR activates the Akt/mTORC1/eIF4E cascade, a detrimental side effect ablated by PP242, which likewise strengthens the antiproliferative feature of DNR therapy in a synergistic fashion. Moreover, PP242 acts as a translation inhibitor of the antiapoptotic protein Mcl-1 by downregulating the Akt/mTORC1/eIF4E signaling pathway (Shi et al. 2015).

Using a pharmacogenetic approach, Pourdehnad et al. (2013) proved that mTOR-dependent phosphorylation of 4E-BP1 is required for tumor cell survival in c-Myc-dependent hematological malignancies. Accordingly, hyperactivation of 4E-BP1 renders c-Myc-driven lymphomas and myelomas druggable by a class of mTOR active site inhibitors capable of impeding 4E-BP1 phosphorylation. The second generation, ATPcompetitive mTOR kinase inhibitor MLN0128 impedes mTOR-dependent 4E-BP1 phosphorylation (Pourdehnad et al. 2013). Confined so far to faithful models of diffuse large B-cell lymphoma, Burkitt's lymphoma, and multiple myeloma, mTOR active site inhibitors show promising therapeutic efficacy across an extensive range of blood-related cancers typified by c-Myc overexpression (Pourdehnad et al. 2013).

\section{Immunomodulating agents}

Immunomodulatory drugs are currently employed in medication management of chronic lymphoblastic leukemia. In monotherapy applications, Lenalidomide and Ofatumumab have proven themselves clinically efficient in patients with episodes of CLL relapse (Ferrajoli et al. 2008, Strati et al. 2016). Lenalidomide pro-apoptotic benefit is exerted via disturbance of the phosphatidylinositol pathway (Herman et al. 2011) and decreased activation of distinctive enzymes; two of such are the oncogenic kinase Akt2 and the pro-survival cascade ERK, both involved in tumorigenesis via eIF4E-mediated mechanism. Importantly, an established mechanism through which Lenalidomide exerts its activity is by decreasing the 
expression of the anti-apoptotic agent Bcl-2 and of the translation checkpoint protein eIF4E (Li et al. 2011). When employed as first medical intervention in CLL patients, this immunomodulating agent showed an encouraging response in long term responder subjects, normalizing the $\mathrm{CD} 4+/ \mathrm{CD} 8+$ cells ratio as well as circulating T lymphocytes (Strati et al. 2013). Although promising altogether (Buhler et al. 2016, Wendtner et al. 2016), warnings on the appearance of secondary cancers following lenalidomide administration, at least in multiple myeloma patients (Usmani et al. 2012), require further enquiry on the safety of this compound.

\section{Multikinase inhibitors}

Inhibition of the mTOR pathway-better if in combination with class I histone deacetylase inhibitorsrepresents a promising treatment strategy for mature B cell neoplasms like mantle cell lymphoma (Simmons et al. 2014), a leukemic condition that shares many features with CLL as a common CD5+ B-cells origin, specific chromosomal aberrations, and clinical presentation (Bentz et al. 2000, Hoeller et al. 2013). The natural polyphenol Resveratrol (RSV) induces significant dephosphorylation of 4E-BP1, cell cycle arrest, apoptosis, and autophagy in T-ALL cells via inhibition of the Akt/mTOR/4E-BP1 pathway (Ge et al. 2013); disappointingly, RSV administration in immunodeficient NOD/SCID mice engrafted with human ALL failed to delay leukemia progression (Zunino et al. 2012).

Sorafenib is an oral drug co-marketed by Bayer and Onyx Pharmaceuticals under the commercial name of Nexavar ${ }^{\circledR}$; as a multikinase inhibitor, it reduces eIF4E phosphorylation level and downregulates the Bcl-2 family member Mcl-1. This small molecule inhibitor significantly downregulates the PI3K/Akt/mTOR pathway, a circuit that controls the activation of eIF4E by regulating the phosphorylation of translation inhibitors 4E-BPs. FDA approved for therapy of several carcinomas, Sorafenib was moreover proven to display significant antileukemic activity in vitro, prospecting opportunities for therapeutic intervention in both ALL (Schult et al. 2010) and CLL (López-Guerra et al. 2012).

\section{Ribavirin}

Whereas active-site inhibitors of mTOR show some promise and inhibitors of eIF4E phosphorylation may emerge as clinical candidates, to date, the sole compound to demonstrate antitumor activity associated with eIF4E inhibition in patients is ribavirin; this same drug is the only direct inhibitor of eIF4E to reach clinical trials (Assouline et al. 2009, Assouline et al. 2015). A guanosine analog, ribavirin suppresses eIF4E-induced transformation by lodging in the binding site devoted to the eIF4E-5' cap interaction (Kentsis et al. 2004, Volpon et al. 2013); consequently, it competes for eIF4E: RNA association, changes the eIF4E subcellular localization and disrupts eIF4E-mediated nuclear-cytoplasmic mRNA export (Culjkovic et al. 2005, Kentsis et al. 2004). A ribavirin-induced switch from nuclear to cytoplasmic eIF4E localization has also been observed in blast cells during clinical studies (Assouline et al. 2009, Assouline et al. 2015). Ribavirin was proposed to act as a physical mimic of the $\mathrm{m} 7 \mathrm{G}$ moiety thereby blocking eIF4E activity (Kentsis et al. 2004); controversially, two independent groups reported on its incapability to function as an mRNA cap analog (Westman et al. 2005, Yan et al. 2005). Incongruences between the original findings and Westman and Yan's results have been later explained as dependent on the experimental conditions (Kentsis et al. 2005). Specific ribavirin loading to the eIF4E cap-binding pocket was further supported by NMR studies with human eIF4E and its non-functional W56A mutant (Volpon et al. 2013). Zahreddine et al. (2014) identified a ribavirin glucuronidation that prevents its binding to eIF4E as a possible causation of drug resistance that developed in patients involved in clinical trial using ribavirin monotherapy to treat refractory AML. This observation provides another evidence for specific interaction between eIF4E and ribavirin in vivo (Zahreddine et al. 2014). However, other ribavirin targets have also been identified. Ribavirin inhibits an inosine monophosphate dehydrogenase (IMPDH) (Yamada et al. 1988), the rate-limiting catalyst of the GTP biosynthesis pathway, leading to reduced levels of cellular guanosine nucleotides. Lowering of intracellular guanosine levels by submillimolar ribavirin treatment was evidenced by Suzuki et al. (2013) who were able to reverse ribavirininduced expression of coagulation Factor VII in HepG2 human hepatoma cells to normal level by adding guanosine to the culture medium (Suzuki et al. 2013). Recently, ribavirin was reported to inhibit histone methyltransferase zeste homolog 2 (EZH2). The same study showed that siRNA-mediated knock-downs of EZH2, eIF4E, IMPDH1 and IMPDH2 led to the substantial growth inhibition of the MCF-7 human breast adenocarcinoma cells. Reduced cell proliferation was not further significantly intensified by ribavirin, giving additional evidence that all these proteins can serve as 
a ribavirin target (De La Cruz-Hernandez et al. 2015). Recent clinical data from a small cohort of lymphoma patients receiving ribavirin therapy to treat viral infection prior or immediately after transplantation suggested that ribavirin may have a significant anti-lymphoma activity (Rutherford et al. 2018). Plausibly, the favorable outcomes of ribavirin treatments are to be attributed to its pleiotropic effects on at least all three known targets (De La Cruz-Hernandez et al. 2015), importance of each of them may differ from tumor to tumor.

Drug resistance is a major clinical difficulty in addressing medical strategies, posing serious public health threats. In the realm of leukemia, developed resistance to chemotherapy interventions can be ascribed, to a degree, to the lymph node microenvironment via induction of pro-survival BCL2 family (Morin 2003). Analog-based nucleosides represent the standard regimen for many leukemic patients; within this framework, it seemed conceivable to assess the contribution of eIF4E to the purine analog fludarabine (FLU) resistance in primary CLL lymphocytes. Genuine eIF4E inhibitors (i.e. Ribavirin and CGP57380) have proven effective adjuvants in sensitizing primary CLL lymphocytes to fludarabine treatment in vitro (Martinez-Marignac et al. 2013). Besides sparse experimental enquiries, the role of eIF4E in drug resistance remains inadequately explored.

\section{EGI-1, an inhibitor of cap-dependent translation}

As earlier reviewed in the text, the assembly of the eIF4E/eIF4G protein complex has a central role in the regulation of gene expression at the translational level. The joining of these two initiation factors is regulated by 4E-BP translational repressors, which compete with eIF4G for binding to the dorsal surface on EIF4E. With the intent to pharmacologically mimic 4E-BP function, Moerke and colleagues (2007) developed a highthroughput screening assay to characterize smallmolecule inhibitors of the eIF4E/eIF4G interaction. The most potent compound identified was 4EGI-1, a synthetic cap-translation inhibitor that binds eIF4E, disrupts eIF4E/eIF4G association, and restrains cap-dependent translation. While 4EGI-1 displaces eIF4G from its eIF4E binding site, it promotes 4E-BP1 association as observed in model systems in vitro (Moerke et al. 2007). Echoing 4E-BPs tumor suppressor activity, this translation inhibitor shows great promise: it decreases cellular expression of oncogenic proteins encoded by weak mRNAs, exhibits activity against multiple cancer cell lines, and preferentially affects transformed cells rather than non-transformed ones (Chen et al. 2012). A recent study (Schwarzer et al. 2014) reports that exposure of T-ALL clones to 4EGI-1 triggers a rapid induction of apoptotic mechanism, while gene set enrichment analysis reveals that mRNAs sensitive to such compound regulate core oncogenic pathways in T-ALL. Some basal mRNA translation is retained following treatment with 4EGI-1, a finding which may justify the low toxicity of this compound on noncancerous tissues (Chen et al. 2012). Synergistic drugs combinations have also been a focus of study. BH3-mimetic inhibitors of the Bcl-2 family of pro-survival proteins belong to a class of chemical compounds currently explored for CLL. When used in a synergistic approach with homology domain 3 (BH3) mimetic ABT-737 agent, 4EGI-1 restores sensitivity to the BCL2 apoptosis via both cap-dependent and capindependent mechanisms in CLL (Willimott et al. 2013), laying the basis for a therapeutically valuable drug combination. The identification of 4EGI-1 inhibitory activity is not only promising for drug discovery but it also equips us with a powerful tool to scrutinize translational control, opening up to new anti-cancer strategies.

\section{A lesson from a failed clinical trial}

Late in 2014, Denovo Biopharma announced the acquisition of enzastaurin, a late-stage oncology drug candidate the development of which was abandoned from Eli Lilly. A serine/threonine kinase inhibitor, this acyclic bisindolylmaleimide suppresses angiogenesis and induces apoptosis in several human cancer cell lines - including B-lymphoid cell lines - by targeting protein kinase $\mathrm{C}$ and PI3K/AKT routes; this latter pathway signaling frees eIF4E via the hierarchical phosphorylation of translational repressors 4E-BPs. Enzastaurin treatment affects signaling through the AKT/mTOR pathway leading to hypophosphorylation of 4E-BP in cancer cells of diverse lineages and showed promises for combination therapy in patients refractory to single drugs alone (Liffraud et al. 2012). Treatment with Enzastaurin increases the amount of eIF4E bound to 4E-BP1 and decreases association of eIF4E with eIF4G, thereby reducing eIF4F translation initiation complex levels. Remarkably, enzastaurin-induced apoptosis is blocked in cancer cells depleted of 4E-BP1 by siRNAs or in 4E-BP1/2 KO murine embryonic fibroblasts cells. Moreover, eIF4E and 4E-BP1 expressions are respectively augmented and diminished in cancer cells exhibiting reduced sensitivity to enzastaurin (Dumstorf et al. 2010). 
Although enzastaurin did not meet primary endpoint in Phase III PRELUDE clinical trial, patients' responsiveness trend in progression-free survival led to its re-evaluation in the realm of genetic analysis. This attests to an emerging trend in the identification of biomarkers correlated with patients' positive responses as late-stage trial candidates may enable personalized targeted therapies and optimize further potential treatments. It further reiterates the importance of modulating eIF4E function-and all together eIF4F levels-indicating 4E-BP1 as a determinant of antileukemic compounds activity in hematological tumor types.

Additional eIF4E family members complicate the therapeutic targeting of the Akt/mTOR/eIF4E pathway

Molecules targeting specific mechanisms of translation upon which selected cells are dependent may represent an unprecedented opportunity for therapeutic success. In this perspective, two additional eIF4E family members termed eIF4E2 and eIF4E3 (Joshi et al. 2004) are worth mentioning. They are speculated to meet specialized roles in regulating mRNA recruitment to the ribosomal structure, conceivably as a result of their different cap binding abilities and interactions with eIF4G and 4E-BPs. eIF4E2 is assumed to be mostly involved in translation repression (Tao et al. 2015). Under hypoxic conditions, eIF4E2 takes part in active translation (Uniacke et al. 2012), congruently with being part of a gene expression signature which underlies an ability of solid primary tumors to form metastases (Ramaswamy et al. 2003). Novel roles are emerging for the least studied eIF4E family member. Overexpression of mouse eIF4E3 reduced growth and foci formation in mouse NIH 3T3 fibroblasts and human U2OS osteosarcoma cell line. Interestingly, the same group observed lower expression of eIF4E3 mRNA in primary human blood specimens from M4/M5 AML patients relative to healthy volunteers (Osborne et al. 2013). In diffuse large B-cell lymphoma, enhanced eIF4E3 expression partly suppresses eIF4E-driven translation while exhibiting a unique translatome (Landon et al. 2014). Recent work on two major variants of the human eIF4E3 isoform, has unveiled that eIF4E3_A but not eIF4E3_B associates with the translation initiation complex (Frydryskova et al. 2016). At the same time, inability of eIF4E3_A to bind 4E-BPs (Joshi et al. 2004) might spare it from the canonical translation control. This raises speculations on whether eIF4E3_A carries out basal translation initiation when eIF4E is repressed. This hypothesis is supported by relocalization of eIF4E3_A to stress granules but not to P-bodies upon a stress insult, whereas canonical eIF4E localizes to both these RNA granules in stress conditions (Frydryskova et al. 2016). It is tempting to hypothesize that eIF4E3_A might secure translation of specific subset of mRNAs which do not respond to changes directed by cellular pathways controlling eIF4E function in translation initiation.

\section{Final remarks}

A thorough understanding of protein synthesis control has a far-reaching potential to shed light on the complex pathogenesis of leukemia, address its clinical management, and develop innovative therapies. We are witnessing an appreciation for targeting factors functioning within the framework of translation initiation as a new opportunity for therapeutic intervention in the realm of the leukemic state. Challenging questions remain yet unanswered concerning leukemic lesions that directly impinge on dysregulated activities of the translational machinery. To identify messenger RNAs pertinent to leukemic transformation, along with components of the translational apparatus that hold leukemogenic potential, would add a crucial piece to the puzzle. Elucidating the clinical significance of eIF4E expression in both ALL and CLL would represent a predictor of clinical outcome and meet a burning medical need for novel targeted therapies and synergistic interventions. Undoubtedly, it would ease the development of drug combinations and contribute to a refinement in clinical management with the prospect of chemo-free strategies as concrete therapeutic alternatives in patients affected by lymphoblastic leukemias.

\section{Conflict of Interest}

There is no conflict of interest.

\section{Acknowledgements}

This work was supported by Ministry of Health of the Czech Republic, project No. NT13713-4. The publication was co-financed by the European Social Fund and the state budget of the Czech Republic, Project No. CZ.1.07/2.3.00/30.0022 and the Czech Science Foundation, project No. GBP305/12/G034.

\section{Abbreviations}

ALL, acute lymphoblastic leukemia; AML, acute 
myelogenous leukemia; BC, blast crisis; Bcl-2, B-cell lymphoma 2; CLL, chronic lymphocytic leukemia; CDK-2, cyclin-dependent kinase 2; CML, chronic myelogenous leukemia; eIF4E, eukaryotic initiation factor 4E; eIF4G, eukaryotic initiation factor 4G; FKBP12, FK506-binding protein; FLU, fludarabine; GAS5, growth arrest-specific 5; IL-4, interleukin 4; IMPDH, inosine monophosphate dehydrogenase; IRF7, interferon regulatory factor 7; LCMV, lymphocytic choriomeningitis virus; MDM2, murine double-minute 2; Mnk, mitogen-activated protein kinase interacting protein kinases; mTORC1/2, mammalian target of rapamycin complex 1 and 2; NHL, non-Hodgkin lymphoma; PABP, poly(A)-binding protein; PDPK1, phosphoinositidedependent protein kinase 1; PI3K, phosphoinositide 3-kinase; PLL, prolymphocytic leukemia; R-FLAT-1, RANTES factor of Late Activated T Lymphocytes-1; RSV, Resveratrol, S6K1, ribosomal protein S6 kinase 1; TAA, tumor-associated antigen; TCR, T-cell receptor; Teff, effector $\mathrm{T}$ cell; Treg, regulatory $\mathrm{T}$ cell; $\mathrm{TSC}$, tuberous sclerosis complex.

\section{References}

ALTMAN JK, GLASER H, SASSANO A, JOSHI S, UEDA T, WATANABE-FUKUNAGA R, FUKUNAGA R, TALLMAN MS, PLATANIAS LC: Negative regulatory effects of Mnk kinases in the generation of chemotherapy-induced antileukemic responses. Mol Pharmacol 78: 778-784, 2010.

ANDREI MA, INGELFINGER D, HEINTZMANN R, ACHSEL T, RIVERA-POMAR R, LUHRMANN R: A role for eIF4E and eIF4E-transporter in targeting mRNPs to mammalian processing bodies. RNA 11: 717-727, 2005.

ARAKI K, TURNER AP, SHAFFER VO, GANGAPPA S, KELLER SA, BACHMANN MF, LARSEN CP, AHMED R: mTOR regulates memory CD8 T-cell differentiation. Nature 460: 108-112, 2009.

ASSOULINE S, CULJKOVIC B, COCOLAKIS E, ROUSSEAU C, BESLU N, AMRI A, CAPLAN S, LEBER B, ROY DC, MILLER WH JR, BORDEN KL: Molecular targeting of the oncogene eIF4E in acute myeloid leukemia (AML): a proof-of-principle clinical trial with ribavirin. Blood 114: 257-260, 2009.

ASSOULINE S, CULJKOVIC-KRALJACIC B, BERGERON J, CAPLAN S, COCOLAKIS E, LAMBERT C, LAU CJ, ZAHREDDINE HA, MILLER WH JR, BORDEN KL: A phase I trial of ribavirin and low-dose cytarabine for the treatment of relapsed and refractory acute myeloid leukemia with elevated eIF4E. Haematologica 100: e7-e9, 2015.

BELLAVIA D, MECAROZZI M, CAMPESE AF, GRAZIOLI P, TALORA C, FRATI L, GULINO A, SCREPANTI I: Notch3 and the Notch3-upregulated RNA-binding protein $\mathrm{HuD}$ regulate Ikaros alternative splicing. EMBO J 26: 1670-1680, 2007.

BENTZ M, PLESCH A, BULLINGER L, STILGENBAUER S, OTT G, MULLER-HERMELINK HK, BAUDIS M, BARTH TF, MOLLER P, LICHTER P, DOHNER H: t(11;14)-positive mantle cell lymphomas exhibit complex karyotypes and share similarities with B-cell chronic lymphocytic leukemia. Genes Chromosomes Cancer 27: 285-294, 2000.

BERETTA L, GINGRAS AC, SVITKIN YV, HALL MN, SONENBERG N: Rapamycin blocks the phosphorylation of 4E-BP1 and inhibits cap-dependent initiation of translation. EMBO J 15: 658-664, 1996.

BERETTA L, SINGER NG, HINDERER R, GINGRAS AC, RICHARDSON B, HANASH SM, SONENBERG N: Differential regulation of translation and eIF4E phosphorylation during human thymocyte maturation. J Immunol 160: 3269-3273, 1998.

BHOJWANI D, YANG JJ, PUI CH: Biology of childhood acute lymphoblastic leukemia. Pediatr Clin North Am 62: 47-60, 2015.

BJUR E, LARSSON O, YURCHENKO E, ZHENG L, GANDIN V, TOPISIROVIC I, LI S, WAGNER CR, SONENBERG N, PICCIRILLO CA: Distinct translational control in CD4+ T cell subsets. Blood 9: 3785, 2013.

BOAL TR, CHIORINI JA, COHEN RB, MIYAMOTO S, FREDERICKSON RM, SONENBERG N, SAFER B: Regulation of eukaryotic translation initiation factor expression during T-cell activation. Biochim Biophys Acta 1176: 257-264, 1993. 
BOLOGNANI F, CONTENTE-CUOMO T, PERRONE-BIZZOZERO NI: Novel recognition motifs and biological functions of the RNA-binding protein $\mathrm{HuD}$ revealed by genome-wide identification of its targets. Nucleic Acids Res 38: 117-130, 2010.

BUXADÉ M, PARRA JL, ROUSSEAU S, SHPIRO N, MARQUEZ R, MORRICE N, BAIN J, ESPEL E, PROUD CG: The Mnks are novel components in the control of TNF alpha biosynthesis and phosphorylate and regulate hnRNP A1. Immunity 23: 177-189, 2005.

CHEN L, AKTAS BH, WANG Y, HE X, SAHOO R, ZHANG N, DENOYELlE S, KABHA E, YANG H, FREEDMAN RY, SUPKO JG, CHOREV M, WAGNER G, HALPERIN JA: Tumor suppression by small molecule inhibitors of translation initiation. Oncotarget 3: 869-881, 2012.

COLINA R, COSTA-MATTIOLI M, DOWLING RJ, JARAMILLO M, TAI LH, BREITBACH CJ, MARTINEAU Y, LARSSON O, RONG L, SVITKIN YV, MAKRIGIANNIS AP, BELL JC, SONENBERG N: Translational control of the innate immune response through IRF-7. Nature 452: 323-328, 2008.

CONSTANTINOU C, ELIA A, CLEMENS MJ: Activation of p53 stimulates proteasome-dependent truncation of eIF4E-binding protein 1 (4E-BP1). Biol Cell 100: 279-289, 2008.

COOK KD, MILLER J: TCR-dependent translational control of GATA-3 enhances Th2 differentiation. J Immunol 185: 3209-3216, 2010.

COOPER HL, BRAVERMAN R: Free fibosomes and growth stimulation in human peripheral lymphocytes: activation of free ribisomes as an essential event in growth induction. J Cell Physiol 93: 213-225, 1977.

CULJKOVIC-KRALJACIC B, BAGUET A, VOLPON L, AMRI A, BORDEN KL: The oncogene eIF4E reprograms the nuclear pore complex to promote mRNA export and oncogenic transformation. Cell Rep 2: 207-215, 2012.

CULJKOVIC B, FERNANDO T, YANG S, MELNICK AM, BORDEN K, CERCHIETTI L: The eukaryotic translation initiation factor 4E (eIF4E) has oncogenic functions and may represent a new therapeutic target in diffuse large B cell lymphoma (DLBCL). Blood 122: 3785, 2013.

CULJKOVIC-KRALJACIC B, FERNANDO TM, MARULLO R, CALVO-VIDAL N, VERMA A, YANG S, TABBÓ F, GAUDIANO M, ZAHREDDINE H, GOLDSTEIN RL, PATEL J, TALDONE T, CHIOSIS G, LADETTO M, GHIONE P, MACHIORLATTI R, ELEMENTO O, INGHIRAMI G, MELNICK A, BORDEN KL, CERCHIETTI L: Combinatorial targeting of nuclear export and translation of RNA inhibits aggressive B-cell lymphomas. Blood 127: 858-868, 2016.

CULJKOVIC B, TOPISIROVIC I, BORDEN KL: Controlling gene expression through RNA regulons: the role of the eukaryotic translation initiation factor eIF4E. Cell Cycle 6: 65-69, 2007.

CULJKOVIC B, TOPISIROVIC I, SKRABANEK M, RUIZ-GUTIERREZ M, BORDEN KL: eIF4E promotes nuclear export of cyclin D1 mRNAs via an element in the 3'UTR. J Cell Biol 169: 245-256, 2005.

DASILVA J, XU L, KIM HJ, MILLER WT, BAR-SAGI D: Regulation of sprouty stability by Mnk1-dependent phosphorylation. Mol Cell Biol 26: 1898-1907, 2006.

DE BENEDETTI A, JOSHI B, GRAFF JR, ZIMMER SG: CHO cells transformed by the translation factor eIF4E display increased c-myc expression, but require overexpression of Max for tumorigenicity. Mol Cell Differ 2: 347-371, 1994.

De FAlCo F, SABATINI R, Del PAPA B, FAlZETTI F, Di JANNI M, SPORTOLETTI P, BALDONI S, SCREPANTI I, MARCONI P, ROSATI E: Notch signaling sustains the expression of Mcl-1 and the activity of eIF4E to promote cell survival in CLL. Oncotarget 6: 16559-16572, 2015.

DE LA CRUZ-HERNANDEZ E, MEDINA-FRANCO JL, TRUJILLO J, CHAVEZ-BLANCO A, DOMINGUEZGOMEZ G, PEREZ-CARDENAS E, GONZALEZ-FIERRO A, TAJA-CHAYEB L, DUEÑAS-GONZALEZ A: Ribavirin as a tri-targeted antitumor repositioned drug. Oncol Rep 33: 2384-2392, 2015.

DUBLIS S, SHAH S, NAND S, ANDERES E: Anemias excluding cobalamin and folate deficiencies. Handb Clin Neurol 120: 1005-1014, 2014.

DUMSTORF CA, KONICEK BW, MCNULTY AM, PARSONS SH, FURIC L, SONENBERG N, GRAFF JR: Modulation of 4E-BP1 function as a critical determinant of enzastaurin-induced apoptosis. Mol Cancer Ther 9: 3158-3163, 2010.

ESPINOSA A, BJORK P, MAGNUSSEN K, MOEN T, SORUM Y: Aberrant expression of the CD8 antigen in B cell chronic lymphocytic leukaemia. Leuk Lymphoma 44: 193-196, 2003. 
FELDMAN ME, APSEL B, UOTILA A, LOEWITH R, KNIGHT ZA, RUGGERO D, SHOKAT KM: Active-site inhibitors of mTOR target rapamycin-resistant outputs of mTORC1 and mTORC2. PLoS Biol 7: e38, 2009.

FINGAR DC, RICHARDSON CJ, ANDREW RT, CHEATHAM L, TSOU C, BLENIS J: mTOR controls cell cycle progression through its cell growth effectors S6K1 and 4E-BP1/Eukaryotic translation initiation factor 4E. Mol Cell Biol 24: 200-216, 2004.

FRYDRYSKOVA K, MASEK T, BORCIN K, MRVOVA S, VENTURI V, POSPISEK M: Distinct recruitment of human eIF4E isoforms to processing bodies and stress granules. BMC Mol Biol 17: 21, 2016.

FURIC L, RONG L, LARSSON O, KOUMAKPAVI IH, YOSHIDA K, BRUESCHKE A, PETROULAKIS E, ROBICHAUD N, POLLAK M, GABOURY LA, PANDOLFI PP, SAAD F, SONENBERG N: eIF4E phosphorylation promotes tumorigenesis and is associated with prostate cancer progression. Proc Natl Acad Sci U S A 107: 14134-14139, 2010.

GE J, LIU Y, LI Q, GUO X, GU L, MA ZG, ZHU YP: Resveratrol induces apoptosis and autophagy in T-cell acute lymphoblastic leukemia cells by inhibiting Akt/mTOR and activating p38-MAPK. Biomed Environ Sci 26: 902-911, 2013.

GIGOUX M, LOVATO A, LECONTE J, LEUNG J, SONENBERG N, SUH WK: Inducible costimulator facilitates T-dependent B cell activation by augmenting IL-4 translation. Mol Immunol 59: 46-54, 2014.

GORENTLA BK, KRISHNA S, SHIN J, INOUE M, SHINOHARA ML, GRAYSON JM, FUKUNAGA R, ZHONG XP: Mnk1 and 2 are dispensable for $T$ cell development and activation but important for the pathogenesis of experimental autoimmune encephalomyelitis. J Immunol 190: 1026-1037, 2013.

GOTHERT JR, BRAKE RL, SMEETS M, DUHRSEN U, BEGLEY CG, IZON DJ: NOTCH1 pathway activation is an early hallmark of SCL T leukemogenesis. Blood 110: 3753-3762, 2007.

GRIFO JA, TAHARA SM, MORGAN MA, SHATKIN AJ, MERRICK WC: New initiation factor activity required for globin mRNA translation. $J$ Biol Chem 258: 5804-5810, 1983.

GUMIREDDY K, LI A, YAN J, SETOYAMA T, JOHANNES GJ, OROM UA, TCHOU J, LIU Q, ZHANG L, SPEICHER DW, CALIN GA, HUANG Q: Identification of a long non-coding RNA-associated RNP complex regulating metastasis at the translational step. EMBO J 32: 2672-2684, 2013.

HEFNER Y, BORSCH-HAUBOLD AG, MURAKAMI M, WILDE JI, PASQUET S, SCHIELTZ D, GHOMASHCHI F, YATES JR 3RD, ARMSTRONG CG, PATERSON A, COHEN P, FUKUNAGA R, HUNTER T, KUDO I, WATSON SP, GELB MH: Serine 727 phosphorylation and activation of cytosolic phospholipase A2 by MNK1-related protein kinases. J Biol Chem 275: 37542-37551, 2000.

HERMAN SE, LAPALOMBELLA R, GORDON AL, RAMANUNNI A, BLUM KA, JONES J, ZHANG X, LANNUTTI BJ, PURI KD, MUTHUSAMY N, BYRD JC, JOHNSON AJ: The role of phosphatidylinositol 3 -kinase- $\delta$ in the immunomodulatory effects of lenalidomide in chronic lymphocytic leukemia. Blood 21: 4323-4327, 2011.

HOELLER S, ZHOU Y, KANAGAL-SHAMANNA R, XU-MONETTE ZY, HOEHN D, BIHL M, SWERDLOW SH, ROSENWALD A, OTT G, SAID J, DUNPHY CH, BUESO-RAMOS CE, LIN P, WANG M, MIRANDA RN, TZANKOV A, MEDEIROS LJ, YOUNG KH: Composite mantle cell lymphoma and chronic lymphocytic leukemia/small lymphocytic lymphoma: a clinicopathologic and molecular study. Hum Pathol 44: 110-121, 2013.

HSU HS, CHEN HW, KAO CL, WU ML, LI AF, CHENG TH: MDM2 is overexpressed and regulated by the eukaryotic translation initiation factor 4E (eIF4E) in human squamous cell carcinoma of esophagus. Ann Surg Oncol 18: 1469-1477, 2011.

HU G, LOU Z, GUPTA M: The long non-coding RNA GAS5 cooperates with the eukaryotic translation initiation factor 4E to regulate c-Myc translation. PLoS One 9: e107016, 2014.

JABBOUR E: Chronic myeloid leukemia: First-line drug of choice. Am J Hematol 91: 59-66, 2016.

JANES MR, LIMON JJ, SO L, CHEN J, LIM RJ, CHAVEZ MA, VU C, LILLY MB, MALLYA S, ONG ST, KONOPLEVA M, MARTIN MB, REN P, LIU Y, ROMMEL C, FRUMAN DA: Effective and selective targeting of leukemia cells using a TORC1/2 kinase inhibitor. Nat Med 16: 205-213, 2010.

JANI P, QI XY, CHANG H: Aberrant expression of T-cell-associated markers CD4 and CD7 on B-cell chronic lymphocytic leukemia. Am J Hematol 82: 73-76, 2007. 
JOSHI B, CAMERON A, JAGUS R: Characterization of mammalian eIF4E-family members. Eur J Biochem 271: 2189-2203, 2004.

JONES RM, BRANDA J, JOHNSTON KA, POLYMENIS M, GADD M, RUSTGI A, CALLANAN L, SCHMIDT EV: An essential E box in the promoter of the gene encoding the mRNA cap-binding protein (eukaryotic initiation factor 4E) is a target for activation by c-myc. Mol Cell Biol 16: 4754-4764, 1996.

JONES SN, HANCOCK AR, VOGEL H, DONEHOWER LA, BRADLEY A: Overexpression of Mdm2 in mice reveals a p53-independent role for Mdm2 in tumorigenesis. Proc Natl Acad Sci U S A 95: 15608-15612, 1998.

KADIA TM, RAVANDI F, CORTES J, KANTARJIAN H: New drugs in acute myeloid leukemia. Ann Oncol 27: 770-778, 2016.

KEDERSHA N, STOECKLIN G, AYODELE M, YACONO P, LYKKE-ANDERSEN J, FRITZLER MJ, SCHEUNER D, KAUFMAN RJ, GOLAN DE, ANDERSON P: Stress granules and processing bodies are dynamically linked sites of mRNP remodeling. J Cell Biol 169: 871-884, 2005.

KENTSIS A, I TOPISIROVIC, B CULJKOVIC, L SHAO, KL BORDEN: Ribavirin suppresses eIF4E-mediated oncogenic transformation by physical mimicry of the 7-methyl guanosine mRNA cap. Proc Natl Acad Sci U S A 101: 18105-18110, 2004.

KENTSIS A, VOLPON L, TOPISIROVIC I, SOLL CE, CULJKOVIC B, SHAO L, BORDEN KL: Further evidence that ribavirin interacts with eIF4E. RNA 11: 1762-1766, 2005.

KONICEK BW, STEPHENS JR, MCNULTY AM, ROBICHAUD N, PEERY RB, DUMSTORF CA, DOWLESS MS, IVERSEN PW, PARSONS S, ELLIS KE, MCCANN DJ, PELLETIER J, FURIC L, YINGLING JM, STANCATO LF, SONENBERG N, GRAFF JR: Therapeutic inhibition of MAP kinase interacting kinase blocks eukaryotic initiation factor 4E phosphorylation and suppresses outgrowth of experimental lung metastases. Cancer Res 71: 1849-1857, 2011.

KRUG U, GANSER A, KOEFFLER HP: Tumor suppressor genes in normal and malignant hematopoiesis. Oncogene 21: 3475-3495, 2002.

LANDON AL, MUNIANDY PA, SHETTY AC, LEHRMANN E, VOLPON L, HOUNG S, ZHANG Y, DAI B, PEROUTKA R, MAZAN-MAMCZARZ K, STEINHARDT J, MAHURKAR A, BECKER KG, BORDEN KL, GARTENHAUS RB: MNKs act as a regulatory switch for eIF4E1 and eIF4E3 driven mRNA translation in DLBCL. Nat Commun 5: 5413, 2014.

LIFFRAUD C, QUILLET-MARY A, FOURNIE JJ, LAURENT G, YSEBAERT L: Protein phosphatase-2A activation is a critical step for enzastaurin activity in chronic lymphoid leukemia cells. Leuk Lymphoma 53: 966-972, 2012.

LI S, PAL R, MONAGHAN SA, SCHAFER P, OUYANG H, MAPARA M, GALSON DL, LENTZSCH S: IMiD immunomodulatory compounds block C/EBP $\{$ beta\} translation through eIF4E down-regulation resulting in inhibition of MM. Blood 117: 5157-5165, 2011.

LIM S, SAW TY, ZHANG M, JANES MR, NACRO K, HILL J, LIM AQ, CHANG CT, FRUMAN DA, RIZZIERI DA, TAN SY, FAN H, CHUAH CT, ONG ST: Targeting of the MNK-eIF4E axis in blast crisis chronic myeloid leukemia inhibits leukemia stem cell function. Proc Natl Acad Sci U S A 110: E2298-E2307, 2013.

LIN CJ, CENCIC R, MILLS JR, ROBERT F, PELLETIER J: c-Myc and eIF4F are components of a feedforward loop that links transcription and translation. Cancer Res 68: 5326-5334, 2008.

LINDQVIST CA, CHRISTIANSSON LH, THORN I, MANGSBO S, PAUL-WETTERBERG G, SUNDSTROM C, TOTTERMAN TH, SIMONSSON B, ENBLAD G, FRISK P, OLSSON-STROMBERG U, LOSKOG ASI: Both CD4+ FoxP3+ and CD4+ FoxP3- T cells from patients with B-cell malignancy express cytolytic markers and kill autologous leukaemic B cells in vitro. Immunology 133: 296-306, 2011.

LOPEZ-GUERRA M, XARGAY-TORRENT S, PEREZ-GALAN P, SABORIT-VILLARROYA I, ROSICH L, VILLAMOR N, AYMERICH M, ROUE G, CAMPO E, MONTSERRAT E, COLOMER D: Sorafenib targets BCR kinases and blocks migratory and microenvironmental survival signals in CLL cells. Leukemia 26: 1429-1432, 2012.

MAMANE Y, PETROULAKIS E, MARTINEAU Y, SATO TA, LARSSON O, RAJASEKHAR VK, SONENBERG $\mathrm{N}$ : Epigenetic activation of a subset of mRNAs by eIF4E explains its effects on cell proliferation. PLoS One $\mathbf{2}$ : e242, 2007. 
MAO X, GREEN JM, SAFER B, LINDSTEN T, FREDERICKSON RM, MIYAMOTO S, SONENBERG N, THOMPSON CB: Regulation of translation initiation factor gene expression during human $\mathrm{T}$ cell activation. J Biol Chem 267: 20444-20450, 1992.

MARTINEZ-MARIGNAC V, SHAWI M, PINEDO-CARPIO E, WANG X, PANASCI L, MILLER W, PETTERSSON F, ALOYZ R: Pharmacological targeting of eIF4E in primary CLL lymphocytes. Blood Cancer J 3: e146, 2013.

MAYR C, BUND D, SCHLEE M, BAMBERGER M, KOFLER DM, HALLEK M, WENDTNER CM: MDM2 is recognized as a tumor-associated antigen in chronic lymphocytic leukemia by CD8+ autologous T lymphocytes. Exp Hematol 34: 44-53, 2006.

MERRICK WC: Cap-dependent and cap-independent translation in eukaryotic systems. Gene 332: 1-11, 2004.

MOERKE NJ, AKTAS H, CHEN H, CANTEL S, REIBARKH MY, FAHMY A, GROSS JD, DEGTEREV A, YUAN J, CHOREV M, HALPERIN JA, WAGNER G: Small-molecule inhibition of the interaction between the translation initiation factors eIF4E and eIF4G. Cell 128: 257-267, 2007.

MONTILLO M, HAMBLIN T, HALLEK M, MONTSERRAT E, MORRA E: Chronic lymphocytic leukemia: novel prognostic factors and their relevance for risk-adapted therapeutic strategies. Haematologica 90: 391-399, 2005.

MORIN PJ: Drug resistance and the microenvironment: nature and nurture. Drug Resist Updat 6: 169-172, 2003.

MUGHAL TI, GOLDMAN J, MUGHAL S: Understanding Leukemias, Lymphomas and Myelomas. CRC Press, Boca Raton, 2009, 188 p.

MUNGAMURI SK, YANG X, THOR AD, SOMASUNDARAM K: Survival signaling by Notch1: mammalian target of rapamycin (mTOR)-dependent inhibition of p53. Cancer Res 66: 4715-4724, 2006.

NIKOLCHEVA T, PYRONNET S, CHOU SY, SONENBERG N, SONG A, CLAYBERGER C, KRENSKY AM: A translational rheostat for RFLAT-1 regulates RANTES expression in T lymphocytes. $J$ Clin Invest 110: 119-126, 2002.

NIU S, CHAN R, BERINI P, WANG C, ZOU S: Morphology and expression status investigations of specific surface markers on B-cell chronic lymphocytic leukemia cells. Microsc Res Tech 76: 1147-1153, 2013.

NTZIACHRISTOS P, TSIRIGOS A, VAN VLIERBERGHE P, NEDJIC J, TRIMARCHI T, FLAHERTY MS, FERRES-MARCO D, DA ROS V, TANG Z, SIEGLE J, ASP P, HADLER M, RIGO I, DE KEERSMAECKER K, PATEL J, HUYNH T, UTRO F, POGLIO S, SAMON JB, PAIETTA E, RACEVSKIS J, ROWE JM, RABADAN R, LEVINE RL, BROWN S, PFLUMIO F, DOMINGUEZ M, FERRANDO A, AIFANTIS I: Genetic inactivation of the polycomb repressive complex 2 in $\mathrm{T}$ cell acute lymphoblastic leukemia. Nat Med 18: 298-301, 2012.

OSBORNE MJ, VOLPON L, KORNBLATT JA, CULJKOVIC-KRALJACIC B, BAGUET B, BORDEN KL: eIF4E3 acts as a tumor suppressor by utilizing an atypical mode of methyl-7-guanosine cap recognition. Proc Natl Acad Sci U S A 110: 3877-3882, 2013.

PALOMERO T, FERRANDO A: Oncogenic NOTCH1 control of MYC and PI3K: challenges and opportunities for anti-NOTCH1 therapy in T-cell acute lymphoblastic leukemias and lymphomas. Clin Cancer Res 14: 5314-5317, 2008.

PALUCH BE, NAGASH AR, BRUMBERGER Z, NEMETH MJ, GRIFFITHS EA: Epigenetics: A primer for clinicians. Blood Rev 30: 285-295, 2016.

RADTKE F, WILSON A, STARK G, BAUER M, VAN MEERWIJK J, MACDONALD HR, AGUET M: Deficient T cell fate specification in mice with an induced inactivation of Notch1. Immunity 10: 547-558, 1999.

RAMASWAMY S, ROSS KN, LANDER ES, GOLUB TR: A molecular signature of metastasis in primary solid tumors. Nat Genet 33: 49-54, 2003.

REDAELLI A, LASKIN BL, STEPHENS JM, BOTTEMAN MF, PASHOS CL: The clinical and epidemiological burden of chronic lymphocytic leukaemia. Eur J Cancer Care (Engl) 13: 279-287, 2004.

RICHES JC, DAVIES JK, MCCLANAHAN F, FATAH R, IQBAL S, AGRAWAI S, RAMSAY AG, GRIBBEN JG: $\mathrm{T}$ cells from CLL patients exhibit features of T-cell exhaustion but retain capacity for cytokine production. Blood 121: 1612-1621, 2013. 
ROSENWALD IB, RHOADS DB, CALLANAN LD, ISSELBACHER KJ, SCHMIDT EV: Increased expression of eukaryotic translation initiation factors eIF-4E and eIF-2 alpha in response to growth induction by c-myc. Proc Natl Acad Sci U S A 90: 6175-6178, 1993.

ROSENWALD IB, KASPAR R, ROUSSEAU D, GEHRKE L, LEBOULCH P, CHEN JJ, SCHMIDT EV, SONENBERG N, LONDON IM: Eukaryotic translation initiation factor 4E regulates expression of cyclin D1 at transcriptional and post-transcriptional levels. J Biol Chem 270: 21176-21180, 1995.

RUGGERO D, MONTANARO L, MA L, XU W, LONDEI P, CORDON-CARDO C, PANDOLFI PP: The translation factor eIF-4E promotes tumor formation and cooperates with c-Myc in lymphomagenesis. Nat Med 10: 484-486, 2004.

RUTHERFORD SC, STEWART EN, CHEN Z, CHADBURN A, WEHRLI NE, VAN BESIEN K, MARTIN P, FURMAN RR, LEONARD JP, CERCHIETTI L: The eIF4E inhibitor ribavirin as a potential antilymphoma therapeutic: early clinical data. Leuk Lymphoma 59: 256-258, 2018.

SCHITTENHELM MM, ILLING B, AHMUT F, RASP KH, BLUMENSTOCK G, DOHNER K, LOPEZ CD, KAMPA-SCHITTENHELM KM: Attenuated expression of apoptosis stimulating protein of p53-2 (ASPP2) in human acute leukemia is associated with therapy failure. PLoS One 8: e80193, 2013.

SCHULT C, DAHLHAUS M, RUCK S, SAWITZKY M, AMOROSO F, LANGE S, ETRO D, GLASS A, FUELLEN G, BOLDT S, WOLKENHAUER O, NERI LM, FREUND M, JUNGHANSS C: The multikinase inhibitor Sorafenib displays significant antiproliferative effects and induces apoptosis via caspase 3, 7 and PARP in B- and T-lymphoblastic cells. BMC Cancer 10: 560, 2010.

SCHMIDT EV, RAVITZ MJ, CHEN L, LYNCH M: Growth controls connect: Interactions between c-myc and the tuberous sclerosis complex-mTOR pathway. Cell Cycle 8: 1344-1351, 1999.

SCHWARZER A, HOLTMANN H, BRUGMAN M, MEYER J, SCHAUERTE C, ZUBER J, STEINEMANN D, SCHLEGELBERGER B, LI Z, BAUM C: Hyperactivation of mTORC1 and mTORC2 by multiple oncogenic events causes addiction to eIF4E-dependent mRNA translation in T-cell leukemia. Oncogene 34: 3593-3604, 2014.

SHI F, YANG X, GONG Y, SHI R, NAREN D, WU J: The antileukemia roles of PP242 alone or in combination with daunorubicin in acute leukemia. Anticancer Drugs 26: 410-421, 2015.

SHIVAROV V, BULLINGER L: Expression profiling of leukemia patients: key lessons and future directions. Exp Hematol 42: 651-660, 2014.

SIMMONS JK, PATEL J, MICHALOWSKI A, ZHANG S, WEI BR, SULLIVAN P, GAMACHE B, FELSENSTEIN K, KUEHL WM, SIMPSON RM, ZINGONE A, LANDGREN O, MOCK BA: TORC1 and class I HDAC inhibitors synergize to suppress mature B cell neoplasms. Mol Oncol 8: 261-272, 2014.

SO L, LEE J, PALAFOX M, MALLYA S, WOXLAND CG, ARGUELLO M, TRUITT ML, SONENBERG N, RUGGERO D, FRUMAN DA: The 4E-BP-eIF4E axis promotes rapamycin-sensitive growth and proliferation in lymphocytes. Sci Signal 9: ra57, 2016.

SONENBERG N, HINNEBUSCH AG: Regulation of translation initiation in eukaryotes: mechanisms and biological targets. Cell 136: 731-745, 2009.

SONENBERG N, MORGAN MA, MERRICK WC, SHATKIN AJ: A polypeptide in eukaryotic initiation factors that crosslinks specifically to the 5'-terminal cap in mRNA. Proc Natl Acad Sci U S A 75: 4843-4847, 1978.

STRATI P, KEATING MJ, WIERDA WG, BADOUX XC, CALIN S, REUBEN JM, O'BRIEN S, KORNBLAU SM, KANTARJIAN HM, GAO H, FERRAIOLI A: Lenalidomide induces long-lasting responses in elderly patients with chronic lymphocytic leukemia. Blood 122: 734-737, 2013.

STRATI P, LANASA M, CALL TG, LEIS JF, BRANDER DM, LAPLANT BR, PETTINGER AM, DING W, PARIKH SA, HANSON CA, CHANAN-KHAN AA, BOWEN DA, CONTE M, KAY NE, SHANAFELT TD: Ofatumumab monotherapy as a consolidation strategy in patients with previously untreated chronic lymphocytic leukaemia: a phase 2 trial. Lancet Haematol 9: 407-414, 2016.

SUZUKI A, MIYAWAKI Y, OKUYAMA E, MURATA M, ANDO Y, KATO I, TAKAGI Y, TAKAGI A, MURATE T, SAITO H, KOJIMA T: Ribavirin-induced intracellular GTP depletion activates transcription elongation in coagulation factor VII gene expression. Biochem J 449: 231-239, 2013. 
TAO X, GAO G: Tristetraprolin recruits eukaryotic initiation factor 4E2 to repress translation of AU-rich element-containing mRNAs. Mol Cell Biol 35: 3921-3932, 2015.

TOPISIROVIC I, SIDDIQUI N, OROLICKI S, SKRABANEK LA, TREMBLAY M, HOANG T, BORDEN KL: Stability of eukaryotic translation initiation factor $4 \mathrm{E} \mathrm{mRNA}$ is regulated by $\mathrm{HuR}$, and this activity is dysregulated in cancer. Mol Cell Biol 29: 1152-1162, 2009.

TOPISIROVIC I, GUZMAN ML, MCCONNELL MJ, LICHT JD, CULJKOVIC B, NEERING SJ, JORDAN CT, BORDEN KL: Aberrant eukaryotic translation initiation factor 4E-dependent mRNA transport impedes hematopoietic differentiation and contributes to leukemogenesis. Mol Cell Biol 23: 8992-9002, 2003.

TZANKOV A, MEIER C, HIRSCHMANN P, WENT P, PILERI SA, DIRNHOFER S: Correlation of high numbers of intratumoral $\mathrm{FOXP}^{+}$regulatory $\mathrm{T}$ cells with improved survival in germinal center-like diffuse large B-cell lymphoma, follicular lymphoma and classical Hodgkin's lymphoma. Haematologica 93: 193-200, 2008.

UEDA T, WATANABE-FUKUNAGA R, FUKUYAMA H, NAGATA S, FUKUNAGA R: Mnk2 and Mnk1 are essential for constitutive and inducible phosphorylation of eukaryotic initiation factor 4E but not for cell growth or development Mol Cell Biol 24: 6539-6549, 2004.

UEDA T, SASAKI M, ELIA AJ, CHIO II, HAMADA K, FUKUNAGA R, MAK TW: Combined deficiency for MAP kinase-interacting kinase 1 and 2 (Mnk1 and Mnk2) delays tumor development. Proc Natl Acad Sci U S A 107: 13984-13990, 2010.

UNIACKE J, HOLTERMAN CE, LACHANCE G, FRANOVIC A, JACOB MD, FABIAN MR, PAYETTE J, HOLCIK M, PAUSE A, LEE S: An oxygen-regulated switch in the protein synthesis machinery. Nature 486: 126-129, 2012.

VOLPON L, OSBORNE MJ, ZAHREDDINE H, ROMEO AA, BORDEN KL: Conformational changes induced in the eukaryotic translation initiation factor eIF4E by a clinically relevant inhibitor, ribavirin triphosphate. Biochem Biophys Res Commun 434: 614-619, 2013.

VU C, FRUMAN DA: Target of rapamycin signaling in leukemia and lymphoma. Clin Cancer Res 16: 5374-5380, 2010.

WANG S, ROSENWALD IB, HUTZLER MJ, PIHAN GA, SAVAS L, CHEN JJ, WODA BA: Expression of the eukaryotic translation initiation factors $4 \mathrm{E}$ and 2alpha in non-Hodgkin's lymphomas. Am J Pathol 155 : 247-255, 1999.

WENDEL HG, SILVA RL, MALINA A, MILLS JR, ZHU H, UEDA T, WATANABE-FUKUNAGA R, FUKUNAGA R, TERUYA-FELDSTEIN J, PELLETIER J, LOWE SW: Dissecting eIF4E action in tumorigenesis. Genes Dev 21: 3232-3237, 2007.

WENDTNER CM, HALLEK M, FRASER GA, MICHALLET AS, HILLMEN P, DURIG J, KALAYCIO M, GRIBBEN JG, STILGENBAUER S, BUHLER A, KIPPS TJ, PURSE B, ZHANG J, DE BEDOUT S, MEI J, CHANAN-KHAN A: Safety and efficacy of different lenalidomide starting doses in patients with relapsed or refractory chronic lymphocytic leukemia: results of an international multicenter double-blinded randomized phase II trial. Leuk Lymphoma 57: 1291-1299, 2016.

WENG AP, FERRANDO AA, LEE W, MORRIS JPT, SILVERMAN LB, SANCHEZ-IRIZARRY C, BLACKLOW SC, LOOK AT, ASTER JC: Activating mutations of NOTCH1 in human T cell acute lymphoblastic leukemia. Science 306: 269-271, 2004.

WESTMAN B, BEEREN L, GRUDZIEN E, STEPINSKI J, WORCH R, ZUBEREK J, JEMIELITY J, STOLARSKI R, DARZYNKIEWICZ E, RHOADS RE, PREISS T: The antiviral drug ribavirin does not mimic the 7-methylguanosine moiety of the mRNA cap structure in vitro. RNA 11: 1505-1513, 2005.

WILLIMOTT S, BECK D, AHEARNE MJ, ADAMS VC, WAGNER SD: Cap-translation inhibitor, 4EGI-1, restores sensitivity to ABT-737 apoptosis through cap-dependent and -independent mechanisms in chronic lymphocytic leukemia. Clin Cancer Res 19: 3212-3223, 2013.

WOLFER A, WILSON A, NEMIR M, MACDONALD HR, RADTKE F: Inactivation of Notch1 impairs VDJbeta rearrangement and allows pre-TCR-independent survival of early alpha beta lineage thymocytes. Immunity 16: 869-879, 2002.

WONG WF, KOHU K, CHIBA T, STATO T, SATAKE M: Interplay of transcription factors in T cell differentiation and function: the role of Runx. Immunology 132: 157-164, 2011. 
YAMADA Y, NATSUMEDA Y, WEBER G: Action of the active metabolites of tiazofurin and ribavirin on purified IMP dehydrogenase. Biochemistry 27: 2193-2196, 1988.

YAMAMOTO JF, GOODMAN MT: Patterns of leukemia incidence in the United States by subtype and demographic characteristics, 1997-2002. Cancer Causes Control 19: 379-390, 2008.

YAN Y, SVITKIN Y, LEE JM, BISAILLON M, PELLETIER J: Ribavirin is not a functional mimic of the 7-methyl guanosine mRNA cap. RNA 11: 1238-1244, 2005.

YOON JH, ABDELMOHSEN K, SRIKANTAN S, YANG X, MARTINDALE JL, DE S, HUARTE M, ZHAN M, BECKER KG, GOROSPE M: LincRNA-p21 suppresses target mRNA translation. Mol Cell 47: 648-655, 2012.

ZAHREDDINE HA, CULJKOVIC-KRALJACIC B, ASSOULINE S, GENDRON P, ROMEO AA, MORRIS SJ, CORMACK G, JAQUITH JB, CERCHIETTI L, COCOLAKIS E, AMRI A, BERGERON J, LEBER B, BECKER MW, PEI S, JORDAN CT, MILLER WH, BORDEN KL: The sonic hedgehog factor GLI1 imparts drug resistance through inducible glucuronidation. Nature 511: 90-93, 2014.

ZHANG L, PAN X, HERSHEY JW: Individual overexpression of five subunits of human translation initiation factor eIF3 promotes malignant transformation of immortal fibroblast cells. J Biol Chem 282: 5790-5800, 2007.

ZHU LF, CHEN XJ, HU JD: Expression of eIF4E in patients with leukemia and its clinical significance. (In Chinese) Zhongguo Shi Yan Xue Ye Xue Za Zhi 21: 1-6, 2013.

ZHU N, GU L, FINDLEY HW, ZHOU M: Transcriptional repression of the eukaryotic initiation factor 4E gene by wild type p53. Biochem Biophys Res Commun 335: 1272-1279, 2005.

ZUNINO SJ, STORMS DH, NEWMAN JW, PEDERSEN TL, KEEN CL, DUCORE JM: Resveratrol given intraperitoneally does not inhibit the growth of high-risk $\mathrm{t}(4 ; 11)$ acute lymphoblastic leukemia cells in a NOD/SCID mouse model. Int J Oncol 40: 1277-1284, 2012. 